\title{
Monascus ruber
}

National Cancer Institute

\section{Source}

National Cancer Institute. Monascus ruber. NCI Thesaurus. Code C127737.

A genus of salt- and acid-tolerant fungi in the phylum Ascomycota. This species is used in the production of pigments. 